\title{
Discovering antimalarials with a differential mode of action
}

\author{
Laura Sanz ${ }^{*}$ Maria Jose Lafuente, Sara Prats, Fernando Neria, María Roncalés, Cristina de Cózar, Ane Rodríguez, \\ María Gómez, Francisco Javier Gamo \\ From Challanges in malaria research: Core science and innovation \\ Oxford, UK. 22-24 September 2014
}

Malaria is a global health problem that causes significant mortality and morbidity, with more than 1 million deaths per year caused by $P$. falciparum. Most antimalarial drugs face decreased efficacy due to the emergence of resistant parasites. Therefore, the efforts to improve current treatments are focused on the identification of new antimalarial drugs displaying novel mechanisms of action.

To increase the probability of success to identify compounds active against all relevant parasite drug targets, phenotypic assays have been used to screen large compound libraries against $P$. falciparum blood stages. At GSK, 2M compounds were screened and 13500 confirmed hits (TCAMS-Tres Cantos Antimalarial Set) were selected which inhibited $P$. falciparum growth with $\mathrm{IC}_{50}$ s below $2 \mu \mathrm{M}$.

In order to select chemotypes with a presumptive novel mechanism of action, an early profiling is carried out which involves several phases:

1. In the first phase, compounds are tested against a wide panel of $P$. falciparum strains with well characterized genetic linkage to drug resistance to establish which series had no cross-resistance with already known antimalarial compounds. Panel includes laboratory strains as well as clinical isolates.

2. In a second phase, compounds are tested using functional assays to identify those molecules interfering with parasite pathways that are targets of already known antimalarials (electron transport, folate and isoprenoid). Both mitochondrial electron transport and pyrimidine biosynthesis inhibitors are identified using transgenic parasites overexpressing Saccharomyces cerevisiae DHODH. Addition of proguanil to cultures restores cytochrome bc1 blockage but not DHODH inhibition. Antifolates are

\footnotetext{
Malaria DPU, Diseases of the Developing World (DDW), GlaxoSmithKline, Tres
} Cantos Madrid, 28760, Spain

(C) 2014 Sanz et al; licensee BioMed Central Ltd. This is an Open Access article distributed under the terms of the Creative Commons

Submit your next manuscript to BioMed Central and take full advantage of:

- Convenient online submission

- Thorough peer review

- No space constraints or color figure charges

- Immediate publication on acceptance

- Inclusion in PubMed, CAS, Scopus and Google Scholar

- Research which is freely available for redistribution 